an additional post of lecturer or senior lecturer in an existing faculty to specialize in the defence aspects of its discipline. Mr. Healey did not envisage initially any restrictions as to the faculties in which these posts should be sot up. Teachers in any of the social or physical seiences or in technology with an interest in defence problems would be encouraged to specialize in their study. Eventually it was hoped that defence studies would emerge as a discipline in its own right in the universities concerned. The Defence White Paper also referred to the organization of short, intra-mural courses in the widest possible variety of subjects. Some of these would be organized in collaboration with the lecturers specially appointed under the arrangements mentioned. Some would be concerned with specific subjects of present and impending interest in the defence fiold. Others would deal with the techniques of management, and it was hoped to collaborate with the business management schools recently established at London and Manchester. These proposals represented a modest step forward on an experimentel basis and at the same time the Government intended to create, within the Ministry of Defence, an organization to undertake, in an atmosphere free from day-to-day problems, research and long-range planning in the defence field. This organization would be designed to enable Britain to earry out research and to attempt to identify problems before they arose and to make available the results of the various studies to all those concerned with the day-to-day formulation and conduct of British defence policy. This activity would be carried on in association with the new university posts of lecturer or senior lecturer which were to be ereated, as well as with other universities or research centres which could help. Close liaison would also be maintained with Government departments concerned.

\section{The Countryside and Leisure}

The White Paper, Leisure in the Countryside: England. and Wales, amplifies slightly the statement on Countryside Parks which the Minister of Land and Notural Resources made to the 'Countryside in 1970' Conference in November 1965. However, it does not moet the real criticism of his proposals (Pp. 15. Cmnd. 2928. London: H.M.S.O. Is, 6d. net). Parliament is to be invited to give elected local bodies the powers and tho financial help they need to ensure that the resources of the countryside match the needs of the nation and to convert the National Parks Commission into a Countryside Commission. This Commission will be responsible for promoting and co-ordinating action and advising the Government on the measures needed for full enjoyment of the countryside and protecting its natural beauty. While reconnaissance, planning and research are proposed locally and nationally pending the introduction of an appropriate Bill, there are no proposals to provide the Commission itself and the Park authorities with either the financial resources or the powers they need for effectivo discharge even of their past responsibilitios. On administration, the Government is content to hopo that for Parks covering more than one county, the planning authorities concerned will consider very seriously the possibility of a change to joint planning boards, although the Government will consider exercising its power to revoko existing arrangemonts if further experience shows this to be required. For the future there will be a 75 per cent grant towards appropriato items of current expenditure and towards loan charges in respoct both of National Parks and Areas of Outstanding Natural Boauty, and it is also proposed that an Exchequer grant at the rate of 75 per cent should be payable towards the additional administrative expenses of National Park Planning Authorities in croating new facilities or improving the landscape. The main instrument for creating County Parks would be the County Councils, and grant will be payable on approved expenditure. Other proposals relate to access to water, both gathering grounds and rivers and canals, to open country, to trees and woodlands. A reference to long-distance routes, however, reads strangely in the light of the commont in the National Parks Commission that progress here has been limited by the financial restrictions the Government itself imposed on the Commission.

\section{Problems of Peace}

IN his 1965 Alex Wood Memorial Lecture, Dilemmas of Peacemaking, Prof. E. G. Rupp concentrates, like R. Ullmann, on what are called 'East-West relations', and from a Christian and historical point of view (Pp. 10. New Malden, Surrey: The Fellowship for Reconciliation. 1965. $2 s$.). Indeed, Prof. Rupp describes his work as an afterthought to Ullmann's pamphlet Dilemmas of a Peacemaker. The experience of the Christian Peace Movement has been to discover men of great understanding, Christian spirit. and integrity, and with more common ground than would have been conceivable if the confrontation between East and West had not been attempted. The confrontation has led to other positive gains, such as the realization of the deep underlying appreciation of the futility and evil of war, the dissolution of the problem of peace into its component parts and the demonstration of its indissoluble links with social justice. Prof. Rupp emphasizes the risk of misunderstandings through the use of such terms as peace, democracy and freedom when different meanings are attached to them, and he urges that the response to appeals to renounce war must be supported with intelligence and determination by millions. $\mathrm{He}_{\mathrm{e}}$ agrees with Lincoln that these groat concepts derive their meaning not from intellectual debate and discussion but from life itself.

\section{New NASA Tracking Antenna}

A NEW automatic tracking antenna, $210 \mathrm{ft}$. in diameter, was dedicated on April 29 at the Goldstone Communications Complex in the Mojave Desert, California. When it becomes operational in May or June it will be used by the National Aeronautics and Space Administration's Deep Space Network for tracking unmanned vehicles in space. The new antenna just completed by the Jet Propulsion Laboratory is a parabolic aluminium dish meas. uring $234 \mathrm{ft}$. from the desert floor to the peak of its apex. The entire structure, including the pedestal, weighs 8,000 tons. Rohr Corporation of San Diego, the prime antenna contractor, and dozens of other firms have taken 6 years to complete this 14 million dollar project.

The enormous size and nearly perfect contour of the " 210 " gives it a greater range and sensitivity than even larger antennae now in operation, such as the $250 \mathrm{ft}$. at Jodrell Bank. Its 715 -ft. circumference forms a circle with an accuracy within $0.05 \mathrm{in}$., and is contoured to an accuracy of less than $0 \cdot 25$ in.

The Goldstone station is the primary station of the Deep Spaco Network, with other stations at Johannesburg, South Africa; Woomera and Canberra, Australia; and Madrid, Spain. This network is used only for tracking and two-way communication with unmanned vehicles, such as the Pioneer and Ranger series and the Venus and Mars probes of the Mariner spacecraft. It is distinct from the other NASA networks such as the Mamned Space Flight Network, which tracks the Gemini and Apollo spacecraft, and the Scientific Satellite Network, which tracks Earth-orbiting scientific, meteorological and communications satellites.

NASA plans to use the " 210 " for continued tracking of the Pioneer VI spacecraft now in orbit around the Sun. With the $85-\mathrm{ft}$. antennae at present being used, the Pioneer could be followed for 6 months, but the more sensitive "210" should increase the useful life of the spacecraft to 14 months.

The reflector and its supporting structure rotate on a hydrostatic bearing. The base of the antenna is a pedestal 